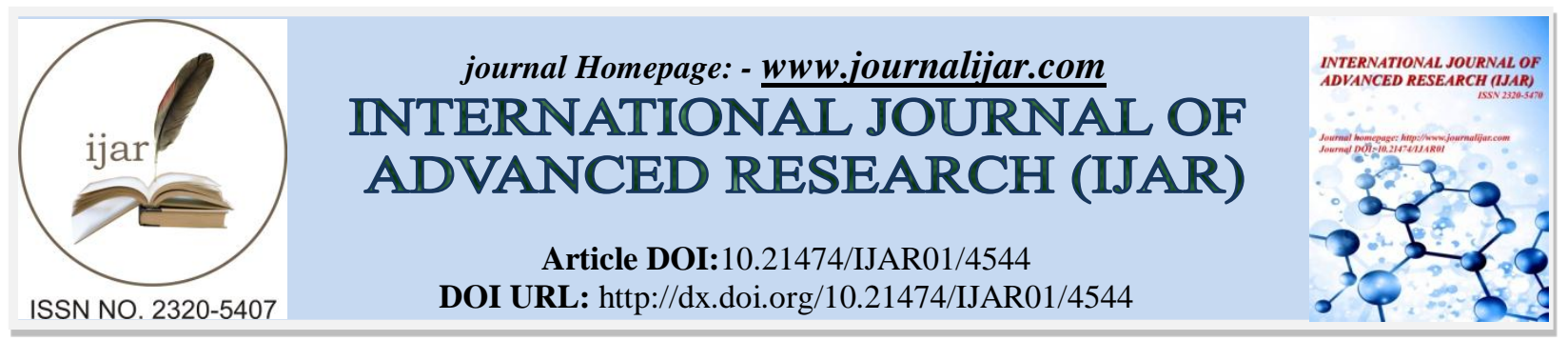

RESEARCH ARTICLE

\title{
AMELIORATIVE POTENTIAL OF MORINGA OR QUERCETIN ON CADMIUM INDUCED TESTICULAR TOXICITY IN ADULT MALE RATS.
}

\author{
Walaa Ahmed Moustafa El-Nahrawy. \\ Zoology Department, Women's College for Arts, Science and Education - Ain ShamsUniversity, Egypt.
}

\section{Manuscript Info}

\section{Manuscript History}

Received: 20 April 2017

Final Accepted: 22 May 2017

Published: June 2017

Key words:-

Cadmium, testicular toxicity, Moringa,

Quercetin, Spermatic quality and

hormonal profile

\section{Abstract}

Cadmium (Cd) is considered to be one of the most abundant environmental contaminants that have a critical threat to human health. It harmfully affects numerous organs in human and animals too. Moringa (M) and quercetin (QE) have ameliorative effects against cadmium toxicity according to their antioxidant possessions. The results designated that $\mathrm{CdCl}_{2}$ induced testicular toxicity through an increase of FSH, LH, E2, Progestrone, $\gamma^{-}$GT and MDA levels while a diminution of Testosterone and GSH levels. Also, testes sperm/ g tissue and total normal sperm count decreased whereas malformed head, tail and head \&tail were increased as a result of $\mathrm{Cd}$ exposure. Treatment by either $\mathrm{M}$ or $\mathrm{QE}$ improved both testes functions, spermatic profile and testicular DNA fragmentation. Thus, the aim of the present study was to evaluate the effectiveness of moringa and quercetin in the restoration of fertility and reproductive function in adult male rats after testicular toxicity induced by cadmium chloride.

Copy Right, IJAR, 2017,. All rights reserved.

\section{Introduction:-}

Infertility in men is one of the most wide spread problem that is of main concern in medicine (Jamsai and O'Bryan, 2011).Several factors are held responsible for such problem some of which are of natural origin (toxic pollutants) or acquired (food and drugs). Cadmium is one of the most toxic pollutants in the biosphere (Goyer\& Clarkson, 2001).Disclosure to $\mathrm{Cd}$ as a result of industrial and environmental pollution leads to grave health threats. Cd has been found to create broad series of biochemical and physiological dysfunctions in humans and laboratory animals (Santos et al., 2004).

Cadmium harms reproductive capability by producing cruel testicular degeneration, seminiferous tubular injury, necrosis, compromised testicular function and reduced androgen secretion in rats (Xu et al., 2005;Ognjanovicet al., 2010 and Yariet al., 2010). The danger of Cd noxiousness is further increased due to its long biological half-life (17-30 years), resulting in accumulating and severe damaging effects (Shukla and Kumar, 2009).

Previous confirmations propose oxidative stress and inflammation played a chief part in the pathogenesis of testicular toxicity and dysfunction induced by cadmium (Gupta et al., 2004; Kara et al., 2005;Suru, 2008 and Predes et al., 2010). Quercetin (QE) as a member of flavonoids and moringa plant have been recognized for having interesting clinical properties, such as antioxidant, anti-inflammatory, antiallergic, antiviral, antibacterial and antitumoral activities (Coskunet al., 2005; Hsu et al ., 2006; Reichard et al., 2007 ; Uygur et al., 2014 andSagit et 
al.,2017 ). Moringaoleifera (MoE) tree is also known as drumstick tree. Moringaoleifera (MoE) comprises precise plant pigments with confirmed vigorous antioxidative ability such as vitamins C, E, A, carotenoids - lutein, alphacarotene and beta carotene, kaempferol, rutin (Aslam et al., 2005).Accordingly, the purpose of this study was to investigate the therapeutic effect of quercetin or moringa on cadmium chloride-induced physiological alterations of the testes (as a natural pollutant in the biosphere) in adult male rats.

\section{Material and Methods:-}

40 adult male Wister rats weighing about $180 \pm 200 \mathrm{~g}$ were used in the present study. They were maintained under standard laboratory conditions at Medical Research Center, Ain Shams University. The experimental procedures complied with guidelines of the Committee on Care and use of Experimental Animal Resources.

\section{Experimental Design:-}

Animal were divided into two experiments .Experiment I, comprising $\mathrm{CdCl}_{2}$ (Sigma Chem.Co.,U.S.A.) measures with control rats (5 rats per group). Group 1 served as the control group. Group 2 were administrated $1 \mathrm{mg} / \mathrm{kg}$ b.wt. $\mathrm{CdCl}_{2}$ intraperitoneally for 4 weeks. Experiment II included the following groups: Group 1 served as control group. Group 2 rats were treated with $50 \mathrm{mg} / \mathrm{kg}$.b.wt. Quercetin (Sigma Chem.Co.,U.S.A.) by oral routes for 30 days. Group 3(M) rats were treated with $400 \mathrm{mg} / \mathrm{kg}$ b.wt. ofMoringaoleifera extract administered orally for 30 days. Group 4 (Recovery) animals treated with $\mathrm{CdCl}_{2}$ then left for 30 days without any treatment. Group $5(\mathrm{Cd}+\mathrm{QE})$ rats treated with $50 \mathrm{mg} / \mathrm{kg}$. b.wt. Quercetin by oral routes for 30 days after cadmium toxicity. Group $6(\mathrm{Cd}+\mathrm{M})$ rats treated with $400 \mathrm{mg} / \mathrm{kg}$ b.wt. ofMoringaoleifera extract administered orally for 30 days after treatment of rats with $\mathrm{CdCl}_{2}$.

\section{Hormones Determination:-}

At the end of experimental period, the rats were slightly anaesthetized and blood collected from the heart in clean dry test tubes. Serum was separated for the assessment of plasma concentrations of luteinizing hormone (LH) (Soos\&Siddle, 1983),follicle-stimulating hormone (FSH) (Concannon, 1986), testosterone (Jaffe\&Behrman, 1974), estradiaol (E2) (Roberttson et al., 1979), progesterone. The hormonal parameters were estimated by Radioimmunoassay (RIA) (Diagnostic Product Corporation (DPC), U.S.A.

Testes were excised and weighed .They were then homogenized in phosphate buffer and then stored in ice for estimation of Gamma-glutamyltransferase (y-GT), glutathione (GSH) content (Beutler and Kelly,1963)and malondialdehyde (MDA) concentration (Pedeson et al.,1990) using commercial ELISA kits (IBL-Hamburg, Germany).

\section{Sperm count \&Morphology:-}

The two caudaepididymus from each rat were dissected, each of them was minced in $2 \mathrm{ml} 0.9 \% \mathrm{NaCl}$. The semen was carefully mixed; the epididymal fluid was subjected to sperm count using Neubauerhaemocytometer (Belsey et al., 1980). Films were spread on clean dray slides, left to dry and stained with HX\&E stain for the examination of sperm morphology.

\section{DNA analysis, Single-cell gel electrophoresis (comet assay):-}

Comet analysis was carried out according to the protocol described by De Boeck et al., 2000. All chemicals and reagents used were obtained from Sigma (Sigma Aldrich, Sigma Chemical Co., St. Louis, Missouri, USA).

\section{Statistical Analysis:-}

Data were statistically analyzed using analysis of variance (ANOVA) followed by Duncan's multiple range test. SPSS (version 16) statistical software was used for the analysis of data and $\mathrm{P}<0.05$ was taken as the level of significance.

\section{Results:-}

\section{Biochemical Analyses:-}

\section{A-Noxious effect of $\mathbf{C d C l}_{2}$}

In experiment (I) treatment of male rats with $\mathrm{CdCl}_{2}$ caused a significant $(\mathrm{p}<0.05)$ increase in $\mathrm{FSH}, \mathrm{LH}, \mathrm{E}_{2}$, Progesterone levels, testicular $\gamma^{-}$GT and MDA. On the other hand, there was a significant decrease in serum testosterone level and testicular GSH activity when compared to the control group Table (1). 


\section{Sperm characteristics:-}

In experiment (I) administration withCdCl2 showed a significant decrease in testes sperm/ g tissue and total normal sperm count while, the number of total malformed, malformed head, malformed tail and malformed head\&tail were significantly increased when compared to the control Table (1)

Table 1:- Biochemical tests of testes function and spermatic characters in rats exposed for 8 weeks to $\mathrm{CdCl}_{2}$

\begin{tabular}{|c|c|c|}
\hline \multirow[t]{2}{*}{ Parameters } & \multicolumn{2}{|c|}{ Groups } \\
\hline & Control & Cd \\
\hline FSH & $3.58 \pm 0.24$ & $5.12 \pm 0.07^{a^{*}}$ \\
\hline LH & $2.25 \pm 0.01$ & $3.88 \pm 0.01^{\mathrm{a}^{*}}$ \\
\hline Testost & $0.558 \pm 0.12$ & $0.188 \pm 0.01^{a^{*}}$ \\
\hline E2 & $15.9 \pm 0.02$ & $26.79 \pm 0.22^{a^{*}}$ \\
\hline Prog & $0.25 \pm 0.003$ & $0.85 \pm 0.02^{\mathrm{a}^{*}}$ \\
\hline $\mathrm{g}$ - GT & $4.66 \pm 0.02$ & $10.98 \pm 0.19^{\mathrm{a}^{*}}$ \\
\hline GSH & $2.54 \pm 0.01$ & $1.66 \pm 0.01^{\mathrm{a}^{*}}$ \\
\hline MDA & $0.185 \pm 0.001$ & $0.287 \pm 0.003^{a^{2}}$ \\
\hline Testes sperm/g tissue & $5.84 \pm 0.01$ & $3.87 \pm 0.02$ \\
\hline Total normal sperm count & $885.8 \pm 3.1$ & $679.2 \pm 4.1^{\mathrm{a}^{*}}$ \\
\hline Malformed Total & $114.2 \pm 3.1$ & $319.6 \pm 4.3^{\mathrm{a}^{*}}$ \\
\hline Malformed Head & $51.2 \pm 1.4$ & $169 \pm 2.4^{a^{*}}$ \\
\hline Malformed Tail & $39.6 \pm 1.2$ & $91.4 \pm 1.4^{\mathrm{a}^{*}}$ \\
\hline Malformed Head\& Tail & $23.8 \pm 0.37$ & $59.2 \pm 1.5^{\mathrm{a}^{*}}$ \\
\hline
\end{tabular}

Means \pm SE of experiment (I); significance from Cont: a., *p<0.05

\section{Recovery effect of $\mathrm{M} \& \mathrm{QE}$ in $\mathbf{C d C l}_{\mathbf{2}}$ induced testicular toxicity:-}

In experiment (II), firstly, there was no significance different in negative control group and groups treated with moringaor quercetin. However, the rats supplemented with $\mathrm{M}$ or $\mathrm{QE}$ after induction toxicity with $\mathrm{CdCl} 2$ showed a significant decrease in FSH, LH, $\mathrm{E}_{2}$, Prog, $\gamma^{-}$GT and MDA levels and an increase in testosterone and GSH levels and did not differ compared with respective values noted in the rats receiving $\mathrm{M}$ or $\mathrm{QE}$ supplementation Tables (2\& 3).Conversely, in recovery (R) group there was a significant difference in its values as compared to the negative control group.

Table 2:-The effect of $\mathrm{M}$ and $\mathrm{QE}$ on hormonal profile after induction of testicular dysfunction by $\mathrm{Cd}$ administration for 4 weeks in male rats

\begin{tabular}{|c|c|c|c|c|c|c|}
\hline Parameters & \multicolumn{6}{|c|}{ Groups } \\
\cline { 2 - 6 } & Control & $\mathbf{M}$ & $\mathbf{Q E}$ & $\mathbf{C d}) \mathbf{R}$ & $\mathbf{C d}+\mathbf{Q E}$ & $\mathbf{C d}+\mathbf{M}$ \\
\hline $\begin{array}{c}\text { FSH } \\
\mathbf{m I U} / \mathbf{m l}\end{array}$ & $3.57 \pm 0.02^{\mathrm{A}}$ & $3.56 \pm 0.01^{\mathrm{A}}$ & $3.56 \pm 0.004^{\mathrm{A}}$ & $4.63 \pm 0.03^{\mathrm{B}}$ & $4.38 \pm 0.05^{\mathrm{C}}$ & $3.92 \pm 0.03^{\mathrm{D}}$ \\
\hline $\mathbf{L H}$ & $2.26 \pm 0.02^{\mathrm{A}}$ & $2.25 \pm 0.01^{\mathrm{A}}$ & $2.23 \pm 0.01^{\mathrm{A}}$ & $3.29 \pm 0.04^{\mathrm{B}}$ & $2.99 \pm 0.04^{\mathrm{C}}$ & $2.59 \pm 0.04^{\mathrm{D}}$ \\
\hline $\begin{array}{c}\text { Testosterone } \\
\mathbf{n g} / \mathbf{m l}\end{array}$ & $0.532 \pm 0.01^{\mathrm{A}}$ & $0.542 \pm 0.01^{\mathrm{A}}$ & $0.540 \pm 0.01^{\mathrm{A}}$ & $0.340 \pm 0.02^{\mathrm{B}}$ & $0.416 \pm 0.02^{\mathrm{C}}$ & $0.492 \pm 0.02^{\mathrm{D}}$ \\
\hline $\begin{array}{c}\mathbf{E 2} \\
\mathbf{P g} / \mathbf{m l}\end{array}$ & $15.89 \pm 0.03^{\mathrm{A}}$ & $16.01 \pm 0.04^{\mathrm{A}}$ & $15.86 \pm 0.03^{\mathrm{A}}$ & $20.42 \pm 0.73^{\mathrm{B}}$ & $18.03 \pm 0.15^{\mathrm{C}}$ & $16.96 \pm 0.07^{\mathrm{D}}$ \\
\hline $\begin{array}{c}\text { Progesterone } \\
\mathbf{n g} / \mathbf{m l}\end{array}$ & $0.256 \pm 0.01^{\mathrm{A}}$ & $0.258 \pm 0.005^{\mathrm{A}}$ & $0.254 \pm 0.01^{\mathrm{A}}$ & $0.574 \pm 0.02^{\mathrm{B}}$ & $0.474 \pm 0.02^{\mathrm{C}}$ & $0.378 \pm 0.02^{\mathrm{D}}$ \\
\hline
\end{tabular}

Values are expressed as mean \pm SE.

$\mathrm{A}, \mathrm{B}, \mathrm{C}, \mathrm{D}$, Means with a common superscript within a row are statically significantly different $(\mathrm{P}<0.05)$.

Table 3:- The effect of $\mathrm{M}$ and $\mathrm{QE}$ on Lipid peroxidation and antioxidant profiles after induction of testicular dysfunction by $\mathrm{Cd}$ administration for 4 weeks in male rats.

\begin{tabular}{|c|c|c|c|c|c|c|}
\hline \multirow{2}{*}{ Parameters } & \multicolumn{5}{|c|}{ Groups } \\
\cline { 2 - 7 } & VeCont & $\mathbf{M}$ & $\mathbf{Q E}$ & $\mathbf{( C d ) ~ R}$ & $\mathbf{C d}+\mathbf{Q E}$ & $\mathbf{C d}+\mathbf{M}$ \\
\hline Testicular f- GT & $4.64 \pm 0.02^{\mathrm{A}}$ & $4.64 \pm 0.02^{\mathrm{A}}$ & $4.63 \pm 0.01^{\mathrm{A}}$ & $8.23 \pm 0.06^{\mathrm{B}}$ & $7.53 \pm 0.09^{\mathrm{C}}$ & $6.05 \pm 0.15^{\mathrm{D}}$ \\
\hline Testicular GSH & $2.51 \pm 0.01^{\mathrm{A}}$ & $2.46 \pm 0.03^{\mathrm{A}}$ & $2.52 \pm 0.01^{\mathrm{A}}$ & $1.89 \pm 0.02^{\mathrm{B}}$ & $1.98 \pm 0.01^{\mathrm{C}}$ & $2.25 \pm 0.02^{\mathrm{D}}$ \\
\hline
\end{tabular}




\begin{tabular}{|c|c|c|c|c|c|c|}
\hline Serum MDA & $0.186 \pm 0.001^{\mathrm{A}}$ & $0.186 \pm 0.001^{\mathrm{A}}$ & $0.187 \pm 0.001^{\mathrm{A}}$ & $0.239 \pm 0.004^{\mathrm{B}}$ & $0.218 \pm 0.004^{\mathrm{C}}$ & $0.199 \pm 0.02^{\mathrm{D}}$ \\
\hline
\end{tabular}

Values are expressed as mean \pm SE.

A,B,C,D,E Means with a common superscript within a row are statically significantly different $(\mathrm{P}<0.05)$.

The administration with moringa or quercetin after exposure to $\mathrm{Cd}$, spermatic profile exhibited differences as testes sperm/ g tissue and total normal sperm count were significantly raised as compared to Cd group. Even though,the number of total malformed, malformed head, malformed tail and malformed head\&tail were significantly reduced when compared to the Cd group Table (4).

Table 4:-Spermatic profile in rats exposed for 4 weeks to $\mathrm{M}$ and QE after exposure to Cd for 4 weeks.

\begin{tabular}{|c|c|c|c|c|c|c|}
\hline \multirow{2}{*}{ Parameters } & \multicolumn{6}{|c|}{ Groups } \\
\hline & - VeCont & $\mathbf{M}$ & $\mathbf{E}$ & (Cd) $R$ & $\mathrm{Cd}+\mathrm{QE}$ & $\mathrm{Cd}+\mathrm{M}$ \\
\hline $\begin{array}{c}\text { Testes sperm/ g } \\
\text { tissue }\end{array}$ & $5.84 \pm 0.01$ & $5.86 \pm 0.01$ & $5.85 \pm 0.01$ & $4.37 \pm 0.03^{\mathrm{a}^{*}}$ & $4.76 \pm 0.03^{\mathrm{d}^{*}}$ & $5.03 \pm 0.16^{\mathrm{d}^{\mathrm{d}}}$ \\
\hline $\begin{array}{l}\text { Total normal } \\
\text { sperm count }\end{array}$ & $888.2 \pm 3$ & $886.6 \pm 3.1$ & $881.8 \pm 3.2$ & $716.4 \pm 6.1^{\mathrm{a}^{*}}$ & $777 \pm 3.7^{\mathrm{d}^{*}}$ & $794.4 \pm 6.3^{\mathrm{d}^{*}}$ \\
\hline $\begin{array}{c}\text { Malformed } \\
\text { Total }\end{array}$ & $111.8 \pm 3$ & $113.4 \pm 3.1$ & $118.2 \pm 3.2$ & $283.6 \pm 6.1^{\mathrm{a}^{*}}$ & $223 \pm 3.7^{\mathrm{d}^{*}}$ & $205.6 \pm 6.3^{d^{*}}$ \\
\hline $\begin{array}{l}\text { Malformed } \\
\text { Head }\end{array}$ & $51.2 \pm 1.4$ & $50.4 \pm 1.03$ & $50.4 \pm 1.2$ & $156.4 \pm 4^{\mathrm{a}^{*}}$ & $127.4 \pm 3^{\mathrm{d}^{*}}$ & $108.4 \pm 4^{\mathrm{d}^{*}}$ \\
\hline Malformed Tail & $40.2 \pm 0.86$ & $40.2 \pm 1.02$ & 39. \pm 0.51 & $73.2 \pm 1.28^{\mathrm{a}^{*}}$ & $57.2 \pm 1.8^{\mathrm{d}^{*}}$ & $59.4 \pm 0.93^{\mathrm{d}^{*}}$ \\
\hline $\begin{array}{l}\text { Malformed } \\
\text { Head\& Tail }\end{array}$ & $34.2 \pm 3.9$ & $28.8 \pm 4.3$ & $35.2 \pm 3.9$ & $55.4 \pm 1.5^{\mathrm{a}^{*}}$ & $38.4 \pm 1.5^{\mathrm{d}^{*}}$ & $39.2 \pm 2.3^{\mathrm{d}^{*}}$ \\
\hline
\end{tabular}

Means \pm SE of experiment (II); significance from -veCont: a.; significance from Cd:d. *p<0.05

\section{Comet assay:-}

Table5 showed the mean values of DNA \% tailed cells as a marker of DNA migration, which reflected DNA fragmentation and damage. In Cd group, the damaged testes cells (tailed cells) increased with a wide variation from -ve control while this change markedly decreased after QE and M treatment. With a similar comparison, the percent of DNA in tails increased while this change decreased after QE and M treatment (Table5 and Fig 1).

Table 5:-DNA analysis of testes cells subjected to single cell gel electrophoresis (comet assay) in rats

\begin{tabular}{|c|c|c|c|c|c|c|}
\hline \multirow[t]{2}{*}{ Parameters } & \multicolumn{6}{|c|}{ Groups } \\
\hline & - veCont & $\mathbf{M}$ & $\mathbf{E}$ & $\mathbf{R}$ & $\mathrm{Cd}+\mathrm{QE}$ & $\mathrm{Cd}+\mathrm{M}$ \\
\hline $\begin{array}{c}\% \text { of tailed } \\
\text { cells(damaged } \\
\text { cells }\end{array}$ & $9.56 \pm 0.01$ & $8.61 \pm 0.67$ & $9.01 \pm 0.31$ & $50.78 \pm 0.45^{\mathrm{a}^{*}}$ & $\begin{array}{l}11.45 \\
\pm 0.05^{\mathrm{d}^{*}}\end{array}$ & $15.05 \pm 0.16^{\mathrm{d}^{*}}$ \\
\hline $\begin{array}{c}\% \text { of DNA in } \\
\text { tail }\end{array}$ & $4.42 \pm 0.82$ & $4.01 \pm 0.84$ & $4.81 \pm 0.71$ & $20.53 \pm 1.76^{\mathrm{a}^{*}}$ & $6.81 \pm 0.81^{\mathrm{d}^{*}}$ & $12.83 . \pm 0.45^{\mathrm{d}^{*}}$ \\
\hline
\end{tabular}

exposed for 4 weeks to $M$ and QE after exposing to Cd for 4 weeks.

Means \pm SE of experiment (II); significance from -veCont: a.; significance from Cd:d. *p<0.05 




Fig 1:- DNA fragment migration patterns by comet assay evaluated with a fluorescence microscope for testes cells, (A): from control rat showing intact cells; most of DNA is located in the head of the comet. (B): from Cd (Recovery group) showing tailed cells, DNA fragmented and migrated from the comet head and formed a tail. (C\&D): From Q $\& \mathrm{M}$ groups showing restoration to the normal intact cells

\section{Discussion:-}

Reproductive toxicity from heavy metal exposure in males is one of the parts of concern in toxicology nowadays due to the highly sensitive cellular composition of the spermatogenic epithelium and the high rate of mitotic activity of the testes. So, this makes the testes more vulnerable to environmental and occupational hazards than other tissues (Queiroz and Waissmann, 2006).Hence, the current study was designed to examine the effect of exposure to cadmium chloride on adult albino rat's seminiferous tubules and to evaluate the promising protective role of moringa and quercetin on such consequences.

The results of this study revealed that $\mathrm{CdCl}_{2}$ administration significantly increased FSH, $\mathrm{LH}, \mathrm{E}_{2}$ and Prog and decreased the level of testosterone. The changes observed in the above agree with the previous reports which demonstrated that cadmium impairs testicular function ( $\mathrm{Li}$ and Heindel, 1998 and Queiroz and Weismann, 2006). Also, $\mathrm{Cd}$ caused a reduction in testes $\mathrm{g} /$ tissue and total count of normal sperm. This diminution may be associated with the impairment of spermatogenesis consequent to decreased secretion of testosterone. Moreover, there was an increase in the total number of malformed sperms. Generation of reactive oxygen species (ROS) by Cd-toxicity and resultant oxidative impairment may increase the meiotic errors and sperm deformation (Acharya et al., 2008). Studies have designated that the exposure to Cd initiates lipid peroxidation, which leads to oxidative stress (Ji et al., 2012; Zhang et al., 2012). Moreover, this study revealed damage of testicular DNA, confirmed by increasing of tailed cells and tail DNA\% of comet analysis that may be attributed to the oxidative stress and cytotoxic effect of $\mathrm{Cd}$, interact with DNA and cause DNA damage, which is a clear symptom of cytotoxicity.

Lipid peroxidation is a progression of oxidative degradation of polyunsaturated fatty acids that lead to damaged membrane structure and function (Goelet al., 2005). ROS, otherwise injure cellular lipids by binding to membrane anionic phospholipids (Sayed-Ahmed and Nagi, 2007), protein and DNA, finally the entire cell (Matés, 2000). The present work, is in agreement with preceding studies, that settled that oxidative stress, increased lipid peroxidation 
and depletion of antioxidant defenses are involved in the pathogenesis of cadmium-induced testicular toxicity (Aktaset al., 2012; Farombiet al., 2012; Fouad \&Jresat, 2013).The imbalance in the lipid peroxidation and antioxidant status of testicular tissue might be providing factor to the decline of testosterone secretion with subsequentinadequate sperm quality (Igeet al., 2012).Therefore, the increase in the testicular MDA and $\gamma$ - GT while the decrease in GSH that occurred in the present study could be due to the concurrent increase in the generation of ROS in Cd- treated group(Abarikwuet al., 2013; Spiazziet al., 2013).

The treatment strategies for $\mathrm{Cd}$ toxicity comprise chelation and antioxidant therapies (Obiohaet al., 2009). The antagonism of moringa and quercetin to Cd- toxicity was evaluated on the basis of biochemical alterations and alterations in sperm characteristics in testes. The present study demonstrated that moringa treatment afforded a significant protective effect against testicular injury caused by cadmium in rats as signified by the improvement in the disturbed biochemical parameters and amelioration of sperm morphological damage. Sreelatha and Padma (2009) in their study revealed that moringaleaves bear a potent antioxidant activity. Theiringredientsscavenge free radicals and employ a protective effect against oxidative destruction induced to cellular macromolecules.

Natural antioxidants that are present in herbs are responsible for inhibiting or blocking the deleterious results of oxidative stress(Akunnaet al., 2012). Quercetin possessesthe ability to avoidthe oxidation of low-density lipoproteins viascavenging free radicals and chelating transition metal ions. Also, antioxidant property of quercetin has been stated to offer significant enhancements in increased LPO level and decreased nonenzymaticantioxidants in testicular tissue as well as declined sperm parameters, DNA damages and decreased testosterone level induced by Cd(Khaki et al., 2010; Ben Abdallah et al., 2011and Ciftciet al., 2012).

\section{Conclusion:-}

In summary, this study contributes to the investigations on the therapeutic influences of moringa and quercetin on testicular toxicity of cadmium. Accordingly, Cd induced disruption to serum, tissue biochemical parameters and testicular DNA fragmentation related to testicular functions. Also, the present result revealed that quercetin possess tremendous antioxidant properties more than moringaon the deleterious effect of $\mathrm{Cd}$ on testes function, hormonal profile and testicular DNA fragmentation.

\section{Reference}

1. Abarikwu, S.O., Iserhienrhien, B.O., Badejo, T.A.(2003):Rutin- and selenium-attenuated cadmium-induced testicular pathophysiology in rats. Hum. Exp.Toxicol., 32:395-406.

2. Acharya, U.R., Mishra, M., Patro, J., Panda, M.K. (2008) :Effect of vitamins C and E on spermatogenesis in mice exposed to cadmium. Reproductive Toxicology, 25 (1): 84-88., 2008

3. Adewoyin, M, Ibrahim, M ., Roszaman, R.; Lokman ,M., Alewi, N.A.; Abdul Rafa,A.A.;and Mohd Nur Nasyriq Anuar,M.N.(2017) :Male Infertility: The Effect of Natural Antioxidants and Phytocompounds on Seminal Oxidative Stress, Diseases, 5:22-29.

4. Aktas, C., Kanter, M., Erboga, M. ,Ozturk, S.(2012):Anti-apoptotic effects of curcumin on cadmium-induced apoptosis in rat testes. Toxicol Ind Health .,28:122-130.

5. Akunna, G.G., Ogunmodede, O.S., Saalu, C.L., Ogunlade, B., Bello, A.J. ,Salawu, E.O.(2012):Ameliorative effect of moringa oleifera(drumstick) leaf extracts on chromium induced testicular toxicity in rat testes. World J. Life Sci. and Med. Res., 2-20.

6. Aslam, M. F., Anwar, R., Nadeem, U., Rashid, T.G.,Kazi, A., Nadeem, M.(2005):Mineral composition of Moringa oleiferaleaves and pods from different regions of Punjab.Pakistan. Asian J. Plant Sci., 4: 417-421.

7. Belsey ,M.A., Moshissi, K.S., Eliasson, R., Paulsen, C.A., Callegos, A.J.,Prasad, M.R. (1980) : Laboratory manual for the examination of human semen and semen cervical mucus interaction. 72-82.

8. Ben Abdallah, F., Fetoui, H., Zribi, N., Fakhfakh, F., Keskes, L. (2012): Quercetin attenuates lambda cyhalothrin-induced reproductive toxicity in male rats. Environ Toxicoldoi: 10., 22-34.

9. Beutler,E.;Kelly,B.(1963):The effect of sodium on RBC glutathione .Journal of Expernita,19,96-103.

10. Ciftci, O., Aydin, M., Ozdemir, I. , Vardi, N.(2012): Quercetin prevents 2,3,7,8-tetrachlorodibenzo-p-dioxin induced testicular damage in rats. Andrologia 44:164-173.

11. Concannon,M.C.(1986):Assessment of follicle stimulation hormone and its application on sera of cycling women.Hormon Res., 29:213.

12. Coskun, O.;Kanter, M.;Korkmaz, A. ;Oter, S.(2005):Quercetin, a flavonoid antioxidant, prevents and protects streptozotocin induced oxidative stress and ß-cell damage in rat Pancreas. Pharmacol. Res., 51:117-123. 
13. De Boeck, M., Touil, N., De Visscher, G., Vande, P.A., Kirsch, V. M.(2000): Validation and implementation of an internal standard in comet assay analysis. Mutat Res.,469, 181-197.

14. Farombi, E.O., Adedara, I.A., Akinrinde, S.A., Ojo, O.O., Eboh, A.S.(2012): Protective effects of kolaviron and quercetin on cadmium induced testicular damage and endocrine pathology in rats. Andrologia, 44:273-284.

15. Fouad, A.A. and Jresat, I.(2013):Captopril and telmisartan treatments attenuate cadmium-induced testicular toxicity in rats. Fundam Clin Pharmacol ,27:152-160.

16. Goel, A., Dani, V., Dhawan, D.K.(2005):Protective effects of zinc on lipid peroxidation, antioxidant enzymes and hepatic histoarchitecture in chlorpyrifos-induced toxicity. Chem Biol Interact., 156:131 -140.

17. Goyer, R.A., and Clarkson, T.W.(2001):Toxic effects of metals. In: Klaassen CD, editor. Casarett \& Doull's Toxicology: The Basic Science of Poisons. $6^{\text {th }}$ ed. New York: McGraw Hill, 811-837.

18. Gupta, R.S., Gupta, E.S.,Dhakal, B.K., Thakur, A.R. ,Ahnn, J.(2004):Vitamin C and vitamin E protect the rat testes from cadmium-induced reactive oxygen species. Mol. Cells, 17:132-139.

19. Hsu, R., Midcap, S., Lucienne de witte, A.L. (2006): Moringa oleifera, Medicinal and Socio-Economic uses. International J. on Economic Botany, 1-25.

20. Ige, S.F., Olaleys, O.A., Akhigbe, R.E., Akanbi, T.A., Oyekunle, O.A. ,Udoh, U.S.(2012): Testicular toxicity and sperm quality following cadmium exposure in rats: Ameliorative potentials of Allium Cepa. J. Hum. Res. Sci., 5 (1): 37- 42.

21. Jaffe,B.M.,Beharman,H.R.(1974):Method of hormone radioimmunoassay. .J.Biol.Chem.,249:7130-7139.

22. Ji, Y.L., Wang, H.,Meng, C., Zhao, X.F., Zhang, C., Zhang, Y., Zhao, M., Chen, Y.H.,Meng, X.H., Xu, D.X.(2012): Melatonin alleviates cadmium-induced cellular stress and germ cell apoptosis in testes. J Pineal Res., 52:71-79.

23. Kara, H., Karatas, F., Canatan, H. and Servi, K.(2005):Effects of exogenous metallothionein on acute cadmium toxicity in rats. Biol. Trace Elem. Res., 104(3):223-232.

24. Khaki, A., Fathiazad, F., Nouri, M., Khaki, A.A., Maleki, N.A., Khamnei, H.J., Ahmadi, P. (2010):Beneficial effects of quercetin on sperm parameters in streptozotocin-induced diabetic male rats. Phytother. Res., 24:12851291.

25. Li, L.H., Heindel, J.J.(1998): Sertoli cell toxicant . In: Korach, K.S., editor. Reproductive and Developmental Toxicology. New York: Marcel Dekker; p.655-691.

26. Matés, J. M.(2000):Effects of antioxidant enzymes in the molecular control of reactive oxygen species toxicology.Toxicology.,153: 83-104.

27. Obioha, U.E., Suru, S.M., OlaMudathir, K.F. ,Faremi, T.Y.(2009):Hepatoprotective potentials of onion and garlic extracts on cadmiuminduced oxidative damage in rats. Biol. Trace. Elem. Res., 129 (1-3): 143-156.

28. Ognjanovic, B.I.,Markovic, S.D.,Ethordevic, N.Z.,Trbojevic, I.S.,Stajn, A.S. ,Saicic, Z.S. (2010):Cadmiuminduced lipid peroxidation and changes in antioxidant defense system in the rat testes: protective role of coenzyme Q(10) and vitamin E, Reprod Toxicol., 29:191-197.

29. Pedeson,M.A.,Scott,C.S.,William,A.B.(1990): Evaluation of lipid peroxidation in inflammatory patients.Ann NY Acad Sci.,559,45.

30. Predes,F.P., Aparecida, S., Diamante,M. ,Heidi ,D.(2010): Testis response to low doses of cadmium in Wistar rats.Int. J. Exp. Pathol., 91(2): 125-131.

31. Queiroz, E.K. ,Waissmann, W.(2006):Occupational exposure and effects on the male reproductive system. Cad. SaúdePúbl., 22:485-493.

32. Reichard, J.F.,Schnekenburger, M. , Puga, A.(2007): Long-term low-dose arsenic exposure induces loss of DNA methylation . Biochem .Biophys. Res. Commun., 352:188-192.

33. Robertson,R.D.,Xing,S.,Goldstein,D.,Febres,F.(1979):Assessment of ovulation by ultrasound and plasma estradiol determination. Obstetric \&Gynecology, 54:686-690.

34. Sagit ,M., Polat, H., Gurgen, S.G .,Berk, E., Guler, S., Yasar, M.(2017): Effectiveness of quercetin in an experimental rat model of allergic rhinitis .Eur Arch Otorhinolaryngol. [Epub ahead of print].

35. Santos, F.W., Oro, T., Zeni, G., Rocha, J.B., Nascimento, P. C., Nogueira,C. W., (2004). Cadmium induced testicular damage and its response to administration of succimer and diphenyl diselenide in mice. Toxicol.Lett., 152: 255-63.

36. Sayed-Ahmed,M.M.,Nagi,M.N.(2007):Thymoquinone supplementation prevents the development of gentamicin-induced renal toxicity in rats. Clin Exp Pharmacol Physiol.,34: 399-405.

37. Shukla, R. , Kumar, M.(2009): Role of Panax ginseng as an antioxidant after cadmium-induced hepatic injuries .Food and Chemical Toxicology, 47(4): 769-773. 
38. Soos,M.,Siddle,K.(1983): Characterization of monoclonal antibodies for human luteinizing hormone and mapping of antigenic determination of hormone".Clin.Chim.Acta.,133(3):263-269.

39. Spiazzi, C.C., Manfredini, V., Barcellos da Silva, F.E., Flores, E.M., Izaguirry, A.P., Vargas, L.M., Soares, M.B., Santos, F.W.(2013): C-Oryzanol protects against acute cadmiuminduced oxidative damage in mice testes". Food Chem Toxicol., 55:526-532.

40. Sreelatha, S. , Padma, P.R. (2009):Antioxidant activity and total phenolic content of M. oleiferaleaves in two stages of maturity. Plant Foods for Human Nutrition, 64(4): 303-311.

41. Suru, S.M., (2008):Onion and garlic extracts lessen cadmium-induced nephrotoxicity in rats. Biometals, 21 (6): $623-633$.

42. Uygur, R., Yagmurca, M., Alkoc, O.A., Genc, A., Songur, A., Ucok, K., Ozen, O.A.(2014):Effects of quercetin and fish n-3 fatty acids on testicular injury induced by ethanol in rats. Andrologia, 46:356-369.

43. Xu, L.C., Sun, H., Wang, S., Song, L., Chang, H.C. , Wang X.R.(2005): The roles of metallothionein on cadmium-induced testes damages in Sprague- Dawley rats. Environ. Toxicol.Pharmacol., 20:83-87.

44. Yari, A.,Asadi, M.H.,Bahadoran, H.,Dashtnavard, H., Imani, H. ,Naghii, M.R.(2010): Cadmium toxicity in spermatogenesis and protective effects of L-carnitine in adult male rats. Biol.Trace. Elem. Res., 137:216-225.

45. Zhang, D.; Gao, J.; Zhang, K.; Liu, X. and Li, J.(2012):Effects of chronic cadmium poisoning on Zn, Cu, Fe, $\mathrm{Ca}$, and metallothionein in liver and kidney of rats". Biological trace element research.,149(1):57-63. 